\title{
AC 2007-1491: GENERATING ENTHUSIASM FOR RESEARCH THROUGH AUTOMOTIVE PROJECTS AND INDUSTRIAL MENTORS: LESSONS LEARNED FROM THE FIRST YEAR OF AN REU PROGRAM
}

\section{Laila Guessous, Oakland University}

LAILA GUESSOUS (Guessous@oakland.edu) is an assistant professor in the department of Mechanical Engineering at Oakland University. She received her M.S. (1994) and Ph.D. (1999) from the University of Michigan and joined OU in August 2000. Her research and teaching interests lie in the areas of fluid mechanics and heat transfer, with an emphasis on computational methods. She is the program director for the NSF and DoD funded Automotive Research and Industrial Mentorship REU program.

\section{Qian Zou, Oakland University}

QIAN ZOU (qzou@oakland.edu) is an assistant professor in the department of Mechanical Engineering at Oakland University. Her research and teaching interests lie in the area of tribology. She is the program co-director for the NSF and DoD funded Automotive Research and Industrial Mentorship REU program.

\section{Brian Sangeorzan, Oakland University}

BRIAN SANGEORZAN (bsangeor@oakland.edu) is an associate professor in the department of Mechanical Engineering at Oakland University. He directs engine research activities at Oakland University and has 23 years experience teaching and conducting research in engine-related fluid and thermal phenomena.

\section{Xia Wang, Oakland University}

XIA WANG (wang@oakland.edu) is an assistant professor in the department of Mechanical Engineering at Oakland University. Her research and teaching interests lie in the areas of fluid mechanics and heat transfer, with an emphasis on fuel cell technology.

\section{Chris Kobus, Oakland University}

CHRIS KOBUS (cjkobus@oakland.edu) is an associate professor in the department of Mechanical Engineering at Oakland University. His research and teaching interests lie in the areas of heat transfer and alternative energy systems.

\section{Gary Barber, Oakland University}

GARY BARBER (barber@oakland.edu) is the chair of the Mechanical Engineering Department at Oakland University. His research and teaching interests lie in the area of tribology.

\section{Alex Alkidas, Oakland University}

ALEX ALKIDAS (alkidas@oakland.edu) recently retired from GM R\&D Center where he spent 29 years as a senior staff research engineer working in the area of experimental engine research. He has for many years been involved in research, teaching and advising activities in the ME department at Oakland University, and is currently serving as an adjunct professor in the department.

\section{Michael Latcha, Oakland University}

MICHAEL LATCHA (latcha@oakland.edu) is an associate professor in the department of Mechanical Engineering at Oakland University. He was the primary person in charge of the assessment of the NSF and DoD funded Automotive Research and Industrial Mentorship REU program. 


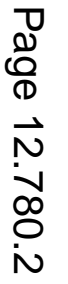




\section{Generating Enthusiasm for Research through Automotive Projects and Industrial Mentors: Lessons Learned from the First Year of an REU Program}

\section{Introduction}

The department of Mechanical Engineering at Oakland University (OU) received funding for three years through the National Science Foundation REU program and the Department of Defense ASSURE program to organize a summer research experience for undergraduates (REU) program that focuses on automotive research. The Automotive Research and Industrial Mentorship (ARIM) REU program at Oakland University ${ }^{1}$ aims to engage participants in rewarding automotive research experiences that excite and motivate them to pursue careers in scientific and engineering research, and seeks to address the nationwide problem of the underrepresentation of women and minorities in the sciences, technology, engineering and math (STEM).

The automotive focus of this program was a natural choice given OU's close ties to and location near the world headquarters and engineering centers of the Big-Three automakers, as well as over one hundred automotive suppliers in southeast Michigan. So, in the summer of 2006, ten undergraduate engineering students from across the United States - half of whom were female spent 10 weeks working in teams of two or three on automotive research projects involving fluid mechanics, heat transfer, energy and/or tribology. Throughout this program, students worked closely with faculty, industrial mentors and graduate students and took part in additional activities such as field trips, seminars, meetings with working engineers and automotive researchers, an SAE conference and short courses on alternative energy. One of the key features of this program was its use of industrial mentors; the industrial mentors are all highly qualified and experienced individuals from the automotive industry who have volunteered to take part in this experience because they have a strong commitment to mentorship and are eager to share their knowledge and experiences with talented young students.

The purpose of this paper is to present some of the lessons learned from the first year of the program. Some of the planning, logistics and procedures will be described. Emphasis will be placed on the lessons learned: what worked, what didn't work and what improvements can be made in the following years. We believe that this type of information would prove useful to others seeking to organize similar programs.

\section{Basic Philosophy of the Program}

The nationwide problem of the under-representation of women in the sciences, technology, engineering and math (STEM) fields is well known and has been well documented ${ }^{2-6}$. While women have been entering and graduating from colleges and universities across the country at record rates (receiving over 57\% of Bachelor's, Master's and doctoral degrees in fields other than the sciences and engineering in 2001), they are not selecting the STEM fields of study that tend to generate the higher salaries and also are necessary for the continued competitiveness of 
the U.S. in a global economy ${ }^{2}$. As can be seen in Figure 1, the percentage of degrees awarded to women in engineering hovers around $20 \%$ and the figures are even lower in the field of mechanical engineering.

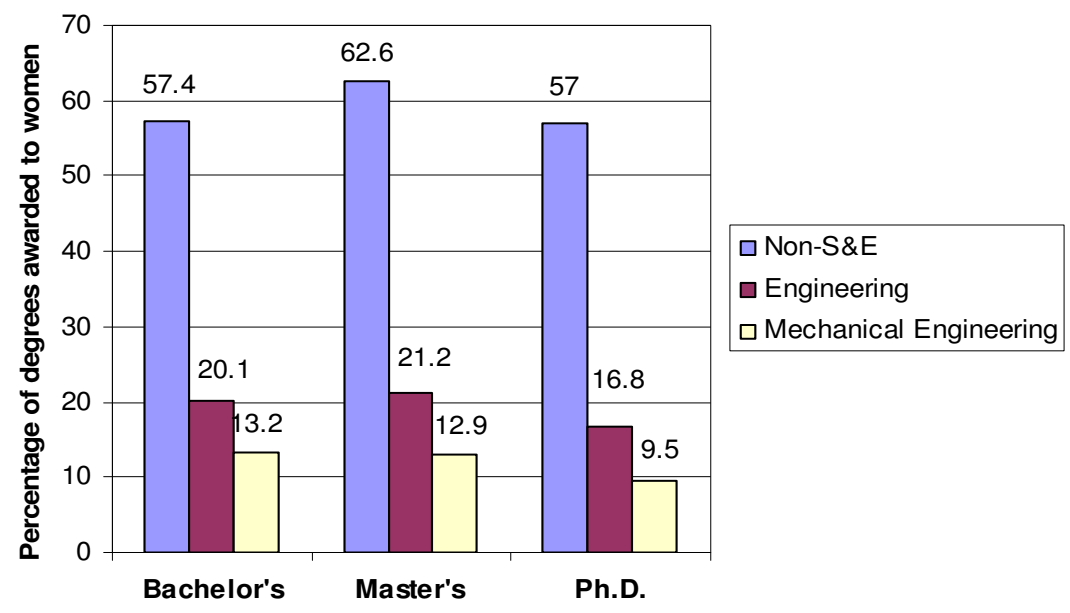

Figure 1 - Nationwide 2001 statistics on undergraduate and graduate degrees awarded to women ${ }^{2}$

The issue of the low representation of women in engineering has clearly been shown not to be one of ability or academic performance ${ }^{3,7}$. Rather, several obstacles to the recruiting and retention of women engineering students have been identified in the literature ${ }^{3,4,8}$. Some worth noting here include a) not knowing what engineers do: this is an obstacle because studies have shown that women tend to want to pick careers that fit their personality (person-environment fit); b) a lack of female engineering role models and a view of engineering as a male-dominated field; c) a lower level of self-confidence among female students than among male students, even when performance levels are the same; d) the effect of socially projected stereotypes about who should be scientists and engineers which pose artificial limits on the participation of talented students in science and engineering and e) the fact that women tend to choose what are considered "helping" professions - this has been a major selling point in increasing the number of women in law and medicine, - and that engineering is not often associated with helping.

A number of programs targeted at recruiting and retaining women in science and engineering have been developed. These include pre-college outreach programs, mentorship through Women in Engineering (WIE) centers, hiring more women faculty, attempts to improve campus climate, etc. The importance of positive one-on-one mentoring and the presence of female role models are quite evident in their positive impact of student self-perception and retention ${ }^{5,9}$. However, numerous studies have shown that active participation in real-life research is one of the most effective ways to attract and retain talented undergraduates and motivate them towards pursuing careers in engineering and science ${ }^{10-13}$. Data indicates that undergraduate students in general, and women and minority students in particular, report increased skills, confidence and motivation to pursue a science or engineering careers as a result of research experiences, positive relations with mentors, supportive campus climate and opportunities to have the students' work recognized through presentations or awards ${ }^{14}$. Undergraduate research is one way for students to feel more connected to their educational experience, to see the value of scientific inquiry in the "real world," to feel a greater sense of empowerment as learners, and just as importantly, to generate enthusiasm about the field ${ }^{15,16}$. A research experience also gives 
them an edge in an increasingly competitive knowledge-based global economy in which the emphasis is as much on what students are capable of learning in the future as it is on how much they know when they graduate. Their ability to adapt quickly to new situations and to solve difficult problems is essential, and research skills greatly enhance that capacity ${ }^{17}$.

It is thus clear that the combination of a meaningful summer research experience, along with a strong mentorship program has the potential to increase the retention rate of undergraduate students in general and women and minority engineering students in particular. This has been a key to the success of a number of other REU programs throughout the U.S ${ }^{18-21}$.

The primary objective of the ARIM REU site is to increase the number of students in mechanical engineering, women in particular, who pursue careers in engineering and embark upon graduate studies to pursue careers in industry, government or academia. This objective is addressed by creating a student-centered, supportive, encouraging, and intellectually stimulating environment that allows talented students to explore challenging new areas, connect them with female and male mentors, refine their communication skills and increase their confidence levels while exploring meaningful and timely, automotive-related research topics in the areas of fluid mechanics, heat transfer and tribology, with a special emphasis on fuel efficiency and alternative fuel sources (fuel cell, biodiesel, and engine technologies). Some of the key aspects of this undergraduate experience are:

1. A strong three-tier mentorship program involving faculty, industrial mentors and graduate students in a mechanical engineering department with higher-than-average women student and faculty representation $(23.9 \%$ and $25 \%$, respectively, compared to national figures of $13.2 \%$ and $6.7 \%)^{2,22,23}$.

2. A commitment from several automotive companies (e.g., General Motors, DaimlerChrysler, Ovonic Fuel Cell Co., FEV Technology) and individuals with extensive industrial experience to provide mentorship to the student researchers and access to laboratory facilities.

3. Exciting projects in an area that has recently been making headlines as a result of the recent increases in oil costs and concerns about oil supplies, demand and national security issues.

4. A number of activities meant to expose students to role models, enhance their confidence levels, improve their communication skills and provide them with the tools and motivation necessary to succeed in their professional or graduate endeavors. Activities include industry and lab tours, seminars, interactions with invited speakers, oral presentations and the opportunity to attend and/or present research findings at a conference.

5. In order to emphasize the importance of professional development, networking and peer support, all students are enrolled in the Society of Women Engineers (SWE) and the Society of Automotive Engineering (SAE).

\section{Application and Recruiting}

The program ran for the first time for ten weeks in the summer of 2006, between May 22 and July 28. Since news of the successful funding of our NSF proposal didn't reach us until mid- 
February 2006, the time frame available for advertising the program was somewhat limited in the first year. Flyers with information about the program and a link to the website ${ }^{1}$ were e-mailed and mailed to a number of institutions nationwide. A link to the program website was setup through the NSF REU page and the following people were contacted:

- Department heads of mechanical engineering programs via e-mail (through a list-serv of ME dept. chairs)

- Faculty advisors of SAE, SWE, SME and NSBE student groups (done by contacting academic liaisons at each of these societies)

- Individual faculty members at various institutions

- Advising coordinators at neighboring community colleges

The program was also advertised on the OU campus using flyers and course announcements by faculty in the School of Engineering and Computer Science (SECS).

The student eligibility requirements were set as follows:

- Open to undergraduate engineering students entering their junior or senior year (graduating after December 2006)

- Must be US citizens or permanent residents.

- GPA: 2.5 or above

- Students cannot be working or taking classes at the same time.

A relatively low GPA requirement was specified in order to allow for applications from students who might not traditionally apply to this type of program and who might greatly benefit from the experience.

Despite the late start and an application deadline of March 20, a total of 56 applications were received from 36 different institutions across the country; 21 of these applications were from female students. This response far exceeded our expectations. Of all the recruiting efforts used, the most effective in the first year were the messages sent to faculty advisors of SAE and SWE, as most of the students had heard about the program through e-mails sent or flyers posted by these advisors. This runs contrary to the experience of others ${ }^{18}$ and might be related to the engineering field considered. Recruiting is currently underway for the coming summer program and we expect to supplement the recruiting efforts by presentations by the former REU students to student groups on their respective campuses (previous programs have found that such word of mouth advertising tends to be the most effective recruiting tool), as well as more outreach to local community colleges to seek to attract more students who have not yet declared engineering as their major.

Our NSF grant provided funding for eight students. However, given the success of the application request and the number of qualified applicants, additional funding was sought and obtained from Oakland University's Office of the Provost and Vice President for Academic Affairs to support two additional OU students, bringing the total number of student participants in the first year to ten. The GPA's of the students varied between 3.1 and 3.96. Five out of the 8 students funded through the NSF and DoD grant were female. None of the students had prior 
research experience and only two had prior co-op or internship experience. A brief profile of these students is listed in Table 1.

Table 2 - Gender, affiliation, major, class level and ethnicity of 2006 ARIM REU participants

\begin{tabular}{|l|l|l|l|l|}
\hline Gender & Affiliation & Major & Class & Ethnicity \\
\hline F & University of Colorado at Boulder & AE & Jr. & Caucasian \\
\hline F & Princeton University & ME & Jr. & Caucasian \\
\hline M & Georgia Institute of Technology & ME & Sr. & Asian American \\
\hline M & University of Oklahoma & ME & Sr. & Caucasian \\
\hline M & Oakland University & ME & Sr. & African American \\
\hline F & University of Idaho & ME & Soph. & Caucasian \\
\hline F & University of New Hampshire & ME & Sr. & Caucasian \\
\hline F & Rochester Institute of Technology & ME & Soph. & Caucasian \\
\hline M & Oakland University & ME & Jr. & Caucasian \\
\hline M & Oakland University & ME & Jr. & Caucasian \\
\hline
\end{tabular}

\section{Program Structure and Activities}

As mentioned previously, the program runs for 10 weeks during the summer. Students receive a $\$ 4,000$ stipend, as well as a small meal allowance and membership to the campus recreational facilities. Travel expenses to OU are reimbursed and all students are provided with a one year membership to SAE and SWE. In the first year, all of the students who came from other institutions were provided with free on-campus housing. As was observed by others ${ }^{18}$, we found that social and professional interactions and bonding between the students increased as a result of shared dormitory accommodations. In fact, three other summer research programs were taking place on the OU campus (Computer science, Biology and Physics) and the students enjoyed interacting with and comparing notes with the participants in those programs. In the first year of the program, the three OU students were not provided with on-campus housing due to limited funding. This did not affect their relation with the other students. In fact, all three students turned out to be wonderful hosts who took it upon themselves to show the other students around campus and town, organize activities and provide transportation when needed. This was a tremendous asset to the program and we highly recommend involving local students in such programs. We would however recommend providing on-campus housing to all of the students, as post-program surveys showed that the OU students felt that they would have benefited from even closer interactions with the other group. Attempts will be made this coming summer to arrange for that.

Students worked in groups of two or three on their respective research projects (these projects are discussed in more detail in the next section). Most of their interactions involved the faculty member supervising their project, graduate students in most cases, and one or two industrial mentors. However, a number of group activities were also organized. These include seminars, meetings with people from industry, lab or industrial facility tours, short courses, an SAE conference and other activities. Listed in Table 2 are some highlights of the schedule of group activities during summer 2006 (Note that not all activities are listed below). 
Table 2 - Highlights of REU Group Activities, Summer 2006

\begin{tabular}{|c|c|}
\hline Week 1 & $\begin{array}{l}\text { Monday, May 22, 2006 - Welcome and Orientation; Introduction of participating } \\
\text { faculty and mentors; Introduction of participating students; Description of REU } \\
\text { program, activities, expectations; Open discussion on research; Lunch with faculty } \\
\text { and industry mentors; Employment paperwork; travel reimbursement paperwork; } \\
\text { campus tour } \\
\text { Tuesday, May 23, 2006 - Project Descriptions: } 15-20 \text { minute overview of each } \\
\text { project; Boxed Lunch; Tour of library and online resources joint with another REU } \\
\text { program on campus; Library study hour } \\
\text { Wednesday, May 24, 2006 - Project Selection: Open discussion with faculty on } \\
\text { projects; Survey on project preference; Project assignment } \\
\text { Friday, May 25, 2006 - Seminar: "Introduction to automotive engines," Tom } \\
\text { Asmus, DaimlerChrysler (ret.); Picnic lunch with faculty and industrial mentors at } \\
\text { the home of one of the industry mentors }\end{array}$ \\
\hline Week 2 & $\begin{array}{l}\text { Tuesday, May 30, 2006 - Overview of Research; Research careers; research } \\
\text { methodologies; ethics, teamwork; research presentations } \\
\text { - Friday, June 2, 2006 - GM R\&D Lab tour and lunch; Seminar: “Automotive } \\
\text { Chassis Systems,” Joe Crowley, DaimlerChrysler Chassis Systems }\end{array}$ \\
\hline Week 3 & $\begin{array}{l}\text { - Friday, June 9, } 2006 \text { - Seminar: "Future of Combustion Research," David Reuss, } \\
\text { GM R\&D } \\
\text { - Saturday, June 10, } 2006 \text { - Short Course - Alternative, Renewable and Sustainable } \\
\text { Energy I: Dr. Chris Kobus, Oakland University }\end{array}$ \\
\hline Week 4 & $\begin{array}{l}\text { - Tuesday, June 13, } 2006 \text {-Tour of DaimlerChrysler Aero-acoustic Wind Tunnel } \\
\text { facility and lunch } \\
\text { - Wednesday, June 14, } 2006 \text { - Uncore Women in computing day (optional) }\end{array}$ \\
\hline Week 5 & $\begin{array}{l}\text { - Tuesday, June 20, } 2006 \text { - Student research presentations } \\
\text { - Saturday, June 25, } 2006 \text { - SAE Young Automotive Professional Conference, } \\
\text { DaimlerChrysler Chelsea Proving grounds }\end{array}$ \\
\hline Week 6 & $\begin{array}{l}\text { Friday, June 30, 2006 - Seminar: “Ovonic Energy Technologies,” Dennis } \\
\text { Corrigan, President and COO Ovonic Fuel Cell Company }\end{array}$ \\
\hline Week 8 & $\begin{array}{l}\text { - Thursday, July 13, 2006 - Tour of FEV Engine Technology } \\
\text { - Friday, July 14, 2006 - Seminar: “Applications of Computational Fluid Dynamics } \\
\text { in the Automotive Industry,” Ken Singh, DaimlerChrysler }\end{array}$ \\
\hline Week 9 & $\begin{array}{l}\text { 1. Tuesday, July 18, } 2006 \text { - Lunch meeting with Meg Novacek, Director, Powertrain } \\
\text { Systems Engineering, DaimlerChrysler }\end{array}$ \\
\hline Week 10 & $\begin{array}{l}\text { 2. Tuesday, July 25, 2006 - Final Project Presentations } \\
\text { 3. Wednesday, July 26, } 2006 \text { - Short Course: Alternative, Renewable and } \\
\text { Sustainable Energy II: Dr. Chris Kobus, Oakland University } \\
\text { 4. Thursday, July 27, 2006 - Tour of Ford Rouge Factory } \\
\text { 5. Friday, July 28, 2006 - Farewell lunch }\end{array}$ \\
\hline
\end{tabular}

This was our first year running the program and much of the planning had to be done as the program progressed. Overall, most of the activities went very well and were very well received by the students. However, based on feedback from the students, faculty and industrial mentors, we will probably make some changes the next time around. Here are some of the recommendations that we would make: 
1. By starting the program on May 22, we ran into memorial day the following Monday, which meant that most campus facilities were closed over the long weekend and the students were essentially on their own less than a week after arriving at OU. We would suggest starting the program either one week earlier or one week later. By starting one week earlier, the students will be more familiar with their surroundings by the time the holiday comes around.

2. We would suggest scheduling most of the tours and seminars earlier in the program. We found that by the $7^{\text {th }}$ or $8^{\text {th }}$ week, students were really absorbed by their projects and getting close to deadlines, and would have generally preferred to have more time to work on their projects!

3. Schedule more lunch meetings with industry professionals of varying backgrounds. These were a great hit and don't require too much time on the part of all involved.

4. Although all of the students met with most of the faculty participants and some of the industrial mentors before/after seminars, we would recommend formalizing such meetings in the sense of blocking out a set time slot each week for all of the groups and participants to get together and discuss their projects or other issues. We found that some faculty members were approached by most of the groups for assistance or feedback on their projects and some weren't. By setting up regular group meetings, we would better foster relations between the students and the faculty and allow for freer exchange of ideas and fresh perspectives.

5. We scheduled the farewell lunch on the last day of the program at Historic Meadow Brook Hall in summer 2006. This lunch brought together all of the students, faculty, graduate students, many of the industry mentors/speakers, laboratory staff and some administrative staff members. Since most of the students left on that day or the following day, we would recommend scheduling this lunch a day before, as this will give the students more time to wrap up their projects, pack up their belongings and feel less rushed at the end.

6. A one and a half day short course on alternative, renewable and sustainable energy was offered to the students. We would recommend cutting that down to either one or two half day courses.

\section{Student Projects}

Five faculty members (all of whom are co-authors on this paper) who work in the areas of fluid/thermal sciences or tribology volunteered to supervise student projects in the summer of 2006. Additional faculty members assisted with some of the group activities and assessment process. All of the faculty and industry participants realized that the goals of this type of undergraduate research experience differ from "standard graduate" projects in that their purpose isn't just to advance knowledge, but also to promote learning and development in the student as well ${ }^{16,24,25}$. Some brief information about potential research projects was provided on the program website and student applicants were asked to rate their top three choices in their application form. They were also asked to provide some information regarding their experimental/laboratory/computing background. This assisted us in selecting the student participants in such a way to ensure a mix of skills, interests and backgrounds. We specifically wanted to include students who had virtually no "hands-on" experience and who would hence 
greatly benefit from this type of experience, but we also wanted to include a few students who were more familiar with automotive components or experimental techniques.

Although we asked the applicants to rate their project preference, we felt that most students wouldn't be able to make a truly informed decision about their project selection, unless they were given "live" information about each project by a faculty member and were given the opportunity to tour the lab facilities and ask questions before listing their preferences. We hence gave an overview of each project on the second day of the program and then asked the students to rank the projects by order of preference on the third day. Project assignment involved taking the students' preferences in mind, as well as trying to pair up appropriate skills and backgrounds to each project. Most students got their first or second choice and were generally pleased with the project assignment process. The list of projects in summer 2006 includes:

1. Wear and Scuffing of Engine Components

2. Investigation of the Effect Bipolar Plate Flow Channel Design on the Performance of PEM Fuel Cells

3. Investigation of Flow Through Engine Valves

4. Experimental Investigation of Gas Temperature Measurement and Heat Transfer in Pulsating Flows

5. Design of a Biodiesel Reprocessor

Projects 1, 2 and 4 were part of ongoing research projects, while project 3 and 5 were specifically designed for the purposes of the REU. Students working on projects 1 and 2 got to conduct some of their testing at industrial facilities, while those working on projects 3 and 4 were given access to components and/or equipment by GM. Most of the projects were experimental and projects 3-5 in particular required the design and development of a new apparatus by the students. All of the students got the opportunity to use experimental techniques or equipment that most undergraduates would rarely get a chance to use and got to interact to varying degrees with faculty, graduate students, industry mentors and staff.

Based on this initial experience, we have learned a few lessons:

1. Involving students in ongoing research projects is more effective for all involved. Students then have more opportunities to work side by side with graduate students and faculty and are more likely to complete their project by the end of the summer. Although there is great learning value to starting a new project from scratch, students will tend to be more satisfied at the end of the semester if they have concrete results to show.

2. If parts or equipment need to be ordered, it might be beneficial to do so prior to the start of the program. This avoids unnecessary delays as students wait for parts to come in

3. Provide training on the use of machine shop tools to all students at the beginning of the program. Although the students were very resourceful and were very good at seeking help from the machine shop staff or teaching each other how to use different tools or equipment when necessary, it would help to level the field somewhat at the beginning of the program. This is especially critical to those students who come in with virtually no hands-on experience and who might feel a bit insecure at the beginning of the program.

4. Groups of two work better than groups of three. 
5. Most of the teams worked very well, with few conflicts or problems. However, this may not be true every year, so we see a need for more formal discussions of teamwork and team roles, as well as sensitivity training for mixed gender or mixed race groups.

\section{Mentorship and Industrial Mentors}

The mentor-mentee relationship can play a crucial role in increasing the likelihood of student research success and degree completion. All of the faculty and industry participants realized that "effective mentoring, similar to effective teaching, does not conform to a specific style, but good mentors may share some common traits, such as the ability to listen well, the desire to be a role model for some facet of students' development, and an interest in helping students to become more skilled and independent in particular areas." ${ }^{26,27}$ Through this REU program, students were provided with three levels of mentoring. The mentoring team consisted of faculty members, industrial mentors and graduate students who were available to assist the REU students with their projects, with their professional socialization and to help foster the personal and professional gains, such as increased confidence, that REU students have reported in other studies ${ }^{10,28}$. We believe that one of the largest untapped resources for mentors and role models is the large number of engineers and researchers who have spent "their whole professional lives within an industrial organization and then retire, ${ }^{29}$ or individuals who are working in research functions within companies, but who wish to be involved with students in an advising and mentoring role. These industrial mentors are all highly qualified and experienced individuals from the automotive industry who have volunteered to take part in this experience because they have a strong commitment to mentorship and are eager to share their knowledge and experiences with talented young students. They bring with them a wealth of knowledge, recent and past experiences working in the automotive and other industries, and the magical power of "real world experience" that so many of us in academia know carries tremendous weight in the eyes of students.

In the case of the ARIM program, the industrial mentors had varied backgrounds and included, among others, a retired senior research executive from one of the Big-Three companies, a few senior researchers and some young engineers early in their careers. Each brought a different set of skills, perspectives and interests to the program, but all, proved invaluable in exciting students about research and graduate school. Some provided guidance or materials for the research projects; others organized laboratory tours, gave seminars, found speakers, or simply had informal discussions with the students.

Although most of the students were pleased with this aspect of the program and realized that this was a unique opportunity for them to interact with people who they would otherwise not have had an opportunity to meet, a number of improvements can be made to this aspect of the program:

1. The lead author, who was also the PI on the NSF grant, was at times reluctant to ask the mentors for additional help, assuming that that would be an encroachment on their time. That was a misguided assumption as the mentors all unanimously indicated at the end of the program that they would have liked to have more involvement with the students and that they at times felt under-utilized. 
2. Although the students were all given the contact information of the mentors and were encouraged by their faculty advisors to contact them, the students were often hesitant to contact them, perhaps for the same misguided reasons as the lead author. For this reason, the level of involvement of the mentors varied from project to project. In some cases, they spent time in the labs "getting their hands dirty" with the students. In other cases, they met with a group on a few occasions to discuss project progress or facilitated the acquisition of necessary equipment or instruments. Most also attended social functions and some of the seminars. We think it would have been beneficial to assign a lead industry mentor to each project (while continuing to tell students that they can contact any of the mentors) and to arrange regular weekly meetings, particularly in the beginning of the program, with the mentors. By increasing the number of face to face interactions at the beginning of the program, we believe that the students will then be less reluctant to make use of all of the resources and help that are available to them throughout the program.

3. We would recommend having some of the industrial mentors discuss the issue of teamwork with the students. We have found that, as in regular classes, students often take what professional from industry say more seriously than what their professors say. The mentors could then focus on the importance of good teamwork in the work environment.

\section{Assessment}

The primary goal of this REU program is to increase engage participants in rewarding research experiences that excite and motivate them to pursue careers in scientific and engineering research. One of the goals of this REU site is to address the nationwide problem of the underrepresentation of women and minorities in the sciences, technology, engineering and math (STEM) and more specifically in the field of mechanical engineering. Assessment is an important component of any project designed to achieve specific goals. If the outcomes of the project are not identified and measured, the success of the project will be unknown. If the measured outcomes are not critically examined and used to improve the program, then any changes made to the program are, by definition, arbitrary. In the process of evaluating our program, efforts are being made to assess both the more subjective and less quantifiable objectives of REU, such as higher personal confidence levels and more favorable perceptions of science and engineering, and the more objective and quantifiable objectives of the program, such as higher recruitment and retention of student majors, successful completion of the degree, and enrollment in graduate programs in engineering. In order to measure these objectives, a variety of assessment tools and approaches are used to gauge the level of success of the REU site. Key aspects of the assessment process include the following:

- Measurement of attitudes, opinions and beliefs about engineering, graduate school, research and the role of women in scientific and engineering professions, by pre/post questionnaires containing both closed and open-ended questions, administered at the beginning and end of every summer REU program. Of particular concern is the effect of socially-projected stereotypes driving who should be scientists and engineers. These cultural influences are known to create artificial limits on the participation of talented young women and minority students and which can negatively impact their self-confidence and academic performance $[30]$. 
- Summative assessment to analyze the impact of the REU experience on the students' academic achievement and educational and professional outcomes. This type of assessment is long-term in nature, requiring that the students who participate in the program be tracked through the remainder of their academic careers (completing their degree, changes in GPA pre- and post-participation, enrollment and completion of graduate programs, etc.), into their working careers (types of employment pursued and accepted, etc.).

- Evaluation of mentoring: A central hypothesis underlying this project is that a strong and positive mentoring relationship is a key ingredient to a successful REU experience, thus we are making efforts to assess this key aspect of the program. Of particular interest to us is whether this component has benefit in the short-term, long-term or both.

- Formative assessment through a survey of participating mentors, to evaluate the impact of the REU experience on the technical and developmental skills of the students.

- Evaluation of REU activities to measure the level of satisfaction and perceived usefulness of the program to students, acknowledging that such perceived usefulness may not show up for several years.

- Evaluation of the projects: At the end of each 10-week session, feedback will be collected from the students, the faculty members and the industrial mentors to evaluate the appropriateness of individual projects for undergraduate research. Reports on undergraduate research in general and REU sites in particular, highlight both the difficulty and importance of project selection on the success of an undergraduate research experience [31, 32].

Additional, less formal feedback is channeled directly to faculty and mentors through their regular meetings and interactions with the students, as well as through regular meetings of the faculty and mentors involved with the program.

Although it is still early to gage the long term effects of this program on the student participants, as we have not yet completed a full cycle of the assessment process, a few things can be surmised from the pre-REU, post-REU and follow-up surveys that the student participants have completed. Some other findings have already been discussed in previous sections.

1. In the pre-REU survey, only one student indicated plans to go to graduate school after graduation. By the post-REU survey, that number had increased to four, with an additional 4 indicating that they would like to work and go to graduate school. The rest were undecided. At least two of the graduating seniors have gone ahead and applied to a number of graduate programs.

2. Based on follow-up surveys and e-mail communications with the students, at least two of the non-graduating students are applying to other research programs for summer 2007.

3. On a scale of 1 to 5 , with 1 being poor and 5 being excellent, students rated their overall REU experience as a 4.7 and all indicated that they would recommend the program to their friends. Most of the activities received ratings above a 4.0. Table 3 lists student responses to the exit survey.

4. Students rated the level of interaction with industry mentors the lowest, not because they did not benefit from or appreciate the interactions (quite the contrary; these got rave 
reviews in their written comments), but rather because of heightened expectations at the beginning of the program. In particular, students expected the mentors to "get their hands dirty" with them in the labs. Some of the changes listed in the previous section ought to address this issue.

5. A follow-up meeting involving the faculty and industry mentors involved with the 2006 REU program was organized following the 2006 summer program as part of the annual assessment of the project selection and mentorship aspects of the program. Some of the key findings from this meeting included: a) recommendations to formalize the involvement of industrial mentors in following years by assigning specific tasks/responsibilities to each mentor, b) a general agreement that the students were able to make quite a bit of progress on their projects despite the short amount of time allocated to them and the difficulty of some of the projects, c) a consensus that all of the students had demonstrated growth and increase in confidence as a result of the program d) a recommendation to, whenever possible, involve students in ongoing research projects.

6. Based on student comments in the exit surveys, concerted efforts will be made by faculty and mentors in following years to clearly show the relevance of each project to the auto industry early in the program and to ensure that students get enough guidance early in the program. Although most of the faculty invested a lot of time into the program, particularly in the early and final weeks, our assessment shows that even more is needed in the first three weeks. It is particularly important to set clear tasks and schedules in the first few weeks, as students familiarize themselves with their new surroundings and teammates. The following excerpt from one of the student comments clearly indicates such a need: "I would have like more hand on guidance in the very beginning because its very hard to find things in a lab you've never been in before and sometimes asking the graduate student meant the student would do whatever you needed rather than show you how to do it. More guidance in the very beginning to establish tasks and make sure that the teams are working efficiently and working as a group towards a common goal would have resulted in a lot more progress in the beginning and a lot less catching up at the halfway point when you have to present your work and motivation. "Eventually, the goal is to help the students develop a sense of independence and ownership of their projects. The level of interactions with all three sets of mentors should progressively diminish as students attain more knowledge and a greater sense of confidence about their projects and their own abilities. As the following student comment shows, students can learn a lot when given the freedom to make their own decisions: "There were times when it would have been seemingly advantageous to be able to be in contact easier and more often, but overall, I think it was much better with the amount of involvement given. They allowed us to figure things out for ourselves, and therefore learn instead of just following what they said." 
Table 3 - Student Responses to Exit Survey, Summer 2006

Please rate the extent to which the program has met your expectations in each of the following categories on a scale of 1 to 5 . Select 1 if the program completely failed to meet your expectations and select 5 if the program has fully met your expectations.

\section{Low -- SATISFACTION -- High}

The opportunity for close interaction with faculty

The opportunity for close interaction with industrial mentors

The opportunity for close interaction with graduate students

Understanding the goals of my research project and how my work will contribute to its success

The opportunity to become familiar with the relevant $1=\mathbf{0} / \mathbf{9} ; 2=\mathbf{0 / 9} ; 3=\mathbf{2} / \mathbf{9} ; 4=\mathbf{4} / \mathbf{9} ; 5=\mathbf{3} \mathbf{9}$; scientific literature for my research project $\mathrm{Avg}=4.1$

Feeling as though I am part of the intellectual effort and not $1=\mathbf{0 / 9} ; 2=\mathbf{0} / \mathbf{9} ; 3=\mathbf{1 / 9} ; 4=\mathbf{5 / 9} ; 5=\mathbf{3} / \mathbf{9}$; just a technical assistant $\operatorname{Avg}=4.2$

Understanding the practical applications of my research $1=0 / 9 ; 2=0 / 9 ; 3=1 / 9 ; 4=4 / 9 ; 5=4 / 9$ Avg $=4.3$

Developing a mentor relationship with faculty on whom I $1=\mathbf{0 / 9} ; 2=\mathbf{0 / 9} ; 3=\mathbf{0 / 9} ; 4=\mathbf{3 / 9} ; 5=\mathbf{6} / \mathbf{9}$ can call for guidance in the future $A v g=4.7$

Developing a mentor relationship with experts from $1=1 / 9 ; 2=0 / 9 ; 3=5 / 9 ; 4=2 / 9 ; 5=1 / 9$; industry on whom I can call for guidance in the future

The opportunity to learn more about other faculty and student projects in addition to my own

Learning more about how to plan for graduate school and careers in mechanical engineering

Learning more about careers in the automotive industry

The opportunity to design an experiment

Developing my experimental and analytical skills

The opportunity for intellectual discussions about the methodologies and ethics of engineering research and practice

Improving my oral presentation skills

Improving my hands-on skills

$1=0 / 9 ; 2=0 / 9 ; 3=2 / 9 ; 4=3 / 9 ; 5=4 / 9$ Avg $=4.2$

$1=0 / 9 ; 2=0 / 9 ; 3=2 / 9 ; 4=4 / 9 ; 5=3 / 9$ $A v g=4.1$

$1=0 / 9 ; 2=0 / 9 ; 3=1 / 9 ; 4=4 / 9 ; 5=4 / 9$ Avg $=4.3$

$1=0 / 9 ; 2=1 / 9 ; 3=0 / 9 ; 4=5 / 9 ; 5=3 / 9$ Avg $=4.1$

$1=0 / 9 ; 2=0 / 9 ; 3=1 / 9 ; 4=3 / 9 ; 5=5 / 9$ Avg $=4.4$

$1=0 / 9 ; 2=0 / 9 ; 3=1 / 9 ; 4=4 / 9 ; 5=4 / 9$ Avg $=4.3$

$1=0 / 9 ; 2=0 / 9 ; 3=1 / 9 ; 4=5 / 9 ; 5=3 / 9$ $\operatorname{Avg}=4.2$

$1=0 / 9 ; 2=0 / 9 ; 3=1 / 9 ; 4=2 / 9 ; 5=6 / 9$ Avg $=4.6$ 


\begin{tabular}{|c|c|}
\hline Improving my self-confidence & $\begin{array}{l}1=0 / 9 ; 2=0 / 9 ; 3=0 / 9 ; 4=5 / 9 ; 5=4 / 9 \\
\text { Avg }=4.4\end{array}$ \\
\hline $\begin{array}{l}\text { Learning more about professional organizations and } \\
\text { networking in engineering and career opportunities }\end{array}$ & $\begin{array}{l}1=0 / 9 ; 2=0 / 9 ; 3=3 / 9 ; 4=4 / 9 ; 5=2 \\
\text { Avg }=3.9\end{array}$ \\
\hline $\begin{array}{r}\text { Doing real engineering rather than following a text book or } \\
\text { lab manual }\end{array}$ & $\begin{array}{l}1=0 / 9 ; 2=0 / 9 ; 3=1 / 9 ; 4=3 / 9 ; 5=5 \\
\text { Avg }=4.4\end{array}$ \\
\hline $\begin{array}{r}\text { Developing relationships and enjoying camaraderie with } \\
\text { other engineering students }\end{array}$ & $\begin{array}{l}1=0 / 9 ; 2=0 / 9 ; 3=2 / 9 ; 4=1 / 9 ; 5=6 / 9 \\
\text { Avg }=4.4\end{array}$ \\
\hline $\begin{array}{r}\text { Making contacts and connections that I expect will pay off } \\
\text { in the future }\end{array}$ & $\begin{array}{l}1=0 / 9 ; 2=0 / 9 ; 3=1 / 9 ; 4=3 / 9 ; 5=5 / 9 \\
\text { Avg }=4.4\end{array}$ \\
\hline $\begin{array}{r}\text { The opportunity to go on field trips to industrial or research } \\
\text { sites }\end{array}$ & $\begin{array}{l}1=0 / 9 ; 2=0 / 9 ; 3=0 / 9 ; 4=2 / 9 ; 5=7 / 9 \\
\text { Avg }=4.8\end{array}$ \\
\hline $\begin{array}{l}\text { The opportunity to attend seminars by speakers from } \\
\text { industry on topics related to automotive engineering }\end{array}$ & $\begin{array}{l}1=0 / 9 ; 2=0 / 9 ; 3=0 / 9 ; 4=4 / 9 ; 5=5 / 9 \\
\text { Avg }=4.6\end{array}$ \\
\hline The opportunity to attend a professional conference & $\begin{array}{l}1=0 / 9 ; 2=0 / 9 ; 3=3 / 9 ; 4=3 / 9 ; 5=3 / 9 \\
\text { Avg }=4\end{array}$ \\
\hline $\begin{array}{r}\text { The opportunity to interact with professionals who have } \\
\text { made a variety of career choices }\end{array}$ & $\begin{array}{l}1=0 / 9 ; 2=0 / 9 ; 3=0 / 9 ; 4=7 / 9 ; 5=2 / 9 \\
\text { Avg }=4.2\end{array}$ \\
\hline $\begin{array}{r}\text { The opportunity to interact with professionals of the same } \\
\text { gender as me }\end{array}$ & $\begin{array}{l}1=0 / 9 ; 2=0 / 9 ; 3=0 / 9 ; 4=4 / 9 ; 5=5 / 9 \\
\text { Avg }=4.6\end{array}$ \\
\hline $\begin{array}{r}\text { The opportunity to interact with professionals of the } \\
\text { opposite gender as me }\end{array}$ & $\begin{array}{l}1=0 / 9 ; 2=0 / 9 ; 3=0 / 9 ; 4= \\
\text { Avg }=4.6\end{array}$ \\
\hline
\end{tabular}

\section{Conclusions}

Setting up and running an REU program is a very time consuming project. It requires a group of dedicated faculty who are willing to work hard over the summer, for little pay, with the ultimate goal of providing a meaningful, exciting and inspiring learning experience for the undergraduate students. The pay-off at the end comes from watching students grow intellectually in a matter of 10 weeks, gain confidence and develop a new-found enthusiasm for the field of engineering. Although, as would be expected in the first year, we ran into some glitches and can do a number of things to improve the program, all of the people involved in the program feel that this was a successful program and look forward to the next few summers. Comments such as the ones listed below (edited for minor typos) make it all worth it!

"Overall this was a great program. I feel that I learned a lot and that I now have more experience under me. I feel like this program was guided enough that I didn't feel too lost, but I was able to explore the research process. I have many positive experiences and memories that I will be sure to share with other students. You were all very supportive and caring. Thank you!" 
"I loved this program and would reccomend it to anyone. I learned a lot and I really feel that I accomplished something at the end of the summer even though I had my doubts all along. This program has really got me thinking about what I want to do with my future and it has made the thought of going to graduate school less scary. If I can get in, I'm going."

"This summer was one of the best experiences I've ever had. Thank you for selecting me."

\section{Acknowledgment}

The authors gratefully acknowledge the support of the National Science Foundation REU program and the Department of Defense ASSURE program through NSF award \# 0552737. They also acknowledge the additional support of Oakland University's Office of the Provost and Vice President for Academic Affairs.

\section{References}

1. For more information, visit http://me-reu.secs.oakland.edu

2. National Science Foundation, Division of Science Resources Statistics, Women, Minorities, and Persons with Disabilities in Science and Engineering: 2004, NSF 04-317 (Arlington, VA, 2004).

3. David Malicky, "A Literature Review on the Under-representation of Women in Undergraduate Engineering: Ability, Self-Eff icacy, and the "Chilly Climate"," Presented at ASEE Annual conference, Nashville, TN, 2003

4. Mary R. Anderson-Rowland, "Why Aren't There More Women in Engineering: Can We Really Do Anything?" Presented at ASEE Annual conference, Nashville, TN, 2003

5. L. J. Bottomley, S. Rajala, and R. Porter, "Women in Engineering at North Carolina State University: An Effort in Recruitment, Retention and Encouragement," presented at ASEE/IEEE Frontiers in Education Conference, San Juan, Puerto Rico, 1999.

6. National Science Foundation, Division of Science Resources Statistics, Characteristics of Doctoral Scientists and Engineers in the United States: 2001, NSF 03-310, Project Officer, Kelly H. Kang (Arlington, VA 2003)

7. R. M. Felder, G. N. Felder, M. Mauney, C.E. Hamrin, Jr, and E. J. Dietz, "A Longitudinal Study of Engineering Student Performance and Retention. III. Gender Differences in Student Performance and Attitudes," Journal of Engineering Education, 84(2), pp. 151-163, 1995.

8. E. Seymour, "The Loss of Women from Science, Mathematics, and Engineering Undergraduate Majors: An Explanatory Account," Science education. 79, no. 4, pp 437, 1995.

9. G.M. Meyer, "Encouraging Female Undergraduate Students; What can a Science Department do?" Journal of college science teaching. XXXII, no. 2, pp. 98-101, 2002

10. E. Seymour, A.-B Hunter, S. Laursen, and T. DeAntoni, T. "Establishing the benefits of research experiences for undergraduates: first findings from a three-year study," Sci. Educ., 88, pp. 493-594, 2004.

11. A.W. Astin, What matters in college? Four critical years revisited. San Francisco: Jossey-Bass., 1993.

12. Pascarella, E. T., \& Terenzini, P. T., How college affects students: Findings and insights from twenty years of research. San Francisco: Jossey-Bass., 1991.

13. Boyer Commission on Educating Undergraduates in the Research University, Reinventing Undergraduate Education: A Blueprint for America's Research Universities,(1998).

14. A. Campbell and G. Skoog, "Preparing Undergraduate Women for Science Careers - Facilitating Success in Professional Research," Journal of college science teaching, 33, no. 5, pp. 24-26, 2004

15. J. Kinkead, "Learning Through Inquiry: An Overview of Undergraduate Research," New Directions For Teaching And Learning, No. 93, Spring 2003 
16. J. L. Murray, P. H. Naimoli, R. S. Kagan, S. M. Kirnan, B.R. Snider, "Reflections on the Use of Undergraduate Research to Support Student Affairs Assessment," Journal of College Student Development, 45(2), March/April 2004.

17. C. Gonzalez, "Undergraduate Research, Graduate Mentoring, and the University's Mission," Science, August 31, v293 i5535 p1624, 2001

18. M. Grant Norton and David F. Bahr, "How to Run a Successful Research Experience for Undergraduates (REU) Site,” ASEE Paper \# 2004-872, 2004

19. Kevin Sutterer, Martin Brenny, J. David Pirnia,, Michelle Woodward, Robert Houghtalen, and Jim Hanson, "Engineering REU Sites: Designing for Appropriate and Valuable Summer Educational Experiences," ASEE Paper \# 2005-2537, 2005

20. Karen M. Haberstroh, and Thomas J. Webster, "A Biomedical Engineering Research Experiences for Undergraduates Program at Purdue University," ASEE Paper \# 2002-1420

21. Geraldine Peten, Anil Sawhney and William Badger, "Overview of Summer Research Program For Undergraduate Students in Construction," ASEE Paper \# 2002-2271

22. Donna J. Nelson and Diana C. Rogers, A National Analysis of Diversity in Science and Engineering Faculties at Research Universities, (Norman, OK, 2003).

23. Data from OU Data Book, https://www2.oakland.edu/secure/oira/ir_home.html

24. T. M. Hakim, At the interface of scholarship and teaching: How to develop and administer institutional undergraduate research programs. Washington, DC: Council on Undergraduate Research. (2000).

25. M. Malachowski, "Not all research is equal: Student-oriented vs. research-oriented approaches to scholarship," Council on Undergraduate Research Quarterly, 17, pp.182-185, 1997.

26. C. Purdy, R. German, U. Ghia, L. Hogeland, and B. Kinkle, "Mentoring Workshops to Support Women Research Students in Science and Engineering," Presented at ASEE Annual conference, Nashville, TN, 2003

27. M. A. Wunsch, "Developing Mentor Programs: Major Themes and Issues." In M. A. Wunsch (ed.). Mentoring Revisited: Making an Impact on Individuals and Institutions. New Directions in Teaching and Learning, no. 57. San Francisco: Jossey-Bass, 1994.

28. C. Merkel, "Undergraduate Research at the Research Universities," New Directions for Teaching and Learning 2003, no. 93 (2003)

29. deStevens, George, "Utilizing Retired Industrial Scientists to Teach Undergraduate Research," Journal of college science teaching. XXII, no. 6, pp. 373-376, May 1993

30. A.Bell, S.J. Spencer, E. Iserman, C. Logel, "Stereotype Threat and Women's Performance in Engineering," Journal of Engineering Education, pp. 307-312, Oct. 2003

31. N. J. Delatte, "Re-engineering an Undergraduate Summer Research Site," Presented at ASEE Annual conference, Nashville, TN, 2003

32. R. M. Marra, R. N. Pangborn, "Mentoring in the Technical Disciplines: Fostering a Broader View of Education, Career, and Culture In and Beyond the Workplace," New Directions for Teaching and Learning, 8 , pp. $35-42,2001$ 